\title{
RESEARCH PAPER \\ THE ROLE OF MARKET WOMEN IN THE INFORMAL URBAN ECONOMY IN KUMASI
}

\author{
T. Y. Baah-Ennumh and G. Adom-Asamoah \\ Department of Planning, KNUST, Kumasi, Ghana.
}

\begin{abstract}
In this paper, the authors examined the role of market women in the informal urban economy and the factors that threaten the effective performance of their roles. Interviewing 360 foodstuff sellers from the Kumasi Central Market and the Race Course Markets, the authors identified that the market women had made significant contributions towards Ghana's fiscal decentralisation through the payment of levies and rents. They have also created jobs, provided incomes for households, ensured food security and sufficiency, and provided a platform for generational development of entrepreneurial skills and competence. However, their roles in the informal economy were constrained by the inadequate basic infrastructure in the markets, limited access to credit facilities and transportation difficulties. The paper therefore recommended the provision of basic life enhancing infrastructure and credit facilities complemented with capacity building in business management.
\end{abstract}

Keywords: Informal Sector, Urban Economy, Women, Traders

\section{INTRODUCTION}

Unemployment and underemployment problems in the developing world have persisted in the urban economy with urbanisation. As urbanisation intensified, poverty also increased due to the inability of job opportunities to expand to absorb the increasing number of people (UNDP, 1999; Owusu, 2005). Urbanisation in Ghana has largely been attributed to rural-urban migration with the urban population increasing from 23 per cent in 1960 to 44 per cent in 2000 and further estimated to increase to 52 per cent by 2010 (Anarfi, et al., 2003; Ghana Statistical Service, 2005). Economic and income disparities between the rural and urban areas which give rise to a perception of availability of jobs in the urban areas appear to be the main driving force behind rural-urban migration (Amis, 1995; Kelly and Williamson, 1984 cited in Ghana Statistical Service, 2005; Owusu, 2005). These factors have contributed largely to the movement of people including women from rural to urban areas.

The informal sector's attribute of ease of entry and exit has provided an employment opportunity to the growing number of people in the urban areas (Garcia-Bolivar, 2006; Bacchetta et al., 2009). According to the International Labour Organisation (ILO), the informal sector provides employment for about 61 per cent of the urban labour force in developing countries of which majority are women (Akintoye, 2006; 2008; ILO, 2000). Similarly, in Ghana, 


\section{7}

women's participation in informal sector employment is estimated at 53.3 per cent in 2005 . The statistics presented elucidate the claim that the informal sector in developing countries is and will continue to be a major source of livelihood to the increasing labour force (Akintoye, 2006; Ghana Statistical Service, 2005).

Despite its significant role in reducing unemployment especially among women, the informal sector in Ghana, like many developing countries, is often underestimated in national accounts (Todaro and Smith, 2009). Hence, public policy for the development of the informal sector has been ambivalent having little impact on the operations of the economic actors in the informal economy (Tsikata, 2001). In recent years however, there is a growing recognition of the importance of the sector and its overwhelming contribution to national development. The intent is to have a true picture of the state of economic affairs in developing countries (Niels-Hugo et al., 2001). The achievement of this is premised on the availability of accurate and reliable information on the role the informal sector plays in national development. It is in view of this that the paper examines the critical roles traders in the Kumasi Central and Race Course markets play in the development of the informal sector within the urban economy.

\section{DATA SOURCES AND METHODS OF COLLECTION}

The paper covered the Kumasi Central and Race Course markets of the Ashanti Region. These markets are known to house diverse informal sector activities ranging from market stall operations to open space trading.

The authors used data from both secondary and primary sources. Secondary data were gathered through desk studies. The desk studies helped the authors to gain insight into the relevant informal sector activities. The primary data were also collected through interviews using both structured and unstructured questionnaires which were complemented by field observa- tion.

The research used stratified sampling technique to select 360 traders. Through the stratified sampling technique, four groups of traders (yam, maize, cassava and plantain sellers) were selected. The simple random sampling technique was then used to select the traders interviewed from the four trading groups (strata). At the Central market, 50 each of yam, maize, cassava and plantain sellers were interviewed; and at the Race Course market, 40 each of yam, maize, cassava and plantain sellers were also interviewed. Twenty Transport operators were interviewed with the intent of triangulating some of the claims made by the traders. The Metropolitan Development Planning Officer of the Kumasi Metropolitan Assembly (KMA), the Market Management, and the Director of the Ashanti Regional Women's Department of the Ministry of Women and Children's Affairs (MOWCA) were interviewed. The interview sought to examine the role of the retailers in the urban economy from their perspective. The data collected from the sellers and institutions were synthesised and analysed using both quantitative and qualitative methods respectively.

\section{RESULTS AND DISCUSSIONS \\ Traders' operating capital and commodities traded in}

Yam, cassava and plantain selling were the preserve of women. However, maize was sold by both men and women. The men and women constituted 18.8 per cent and 81.2 per cent respectively of the total number of maize sellers interviewed. A probe revealed that due to the relatively lower operating capital ranging between GH $\varnothing 100-3,000$ for majority of the women, they traded in yam, cassava and plantain. Since these products are perishable, they are traded in smaller quantities to enable easy disposal. On the other hand, the men with relatively higher operating capital (ranging between $\mathrm{GH} ф 2,670$ - 3,270 as indicated in Table 3 ) traded in non-perishable foodstuffs in larger quantities which does not require frequent commuting between the producing areas and the 
market centres. The dominance of women in the sale of yam, cassava and plantain which were traded in smaller quantities confirms Todaro and Smith's claim that enterprises run by women are smaller in size (Todaro and Smith, 2009).

\section{Sources of the foodstuffs}

The plantain sellers purchased the plantain from the forest areas of the Brong Ahafo Region (Goaso and its environs), Western Region (Bibiani and its environs), Ashanti Region (Nyinahini and Tepa). The cassava sellers also acquired their foodstuffs from the forest regions of Ghana. The major sources of the foodstuffs among others were Offinso, Anhwia-Nkwanta, Mankranso, Bekwai, Jacobu and Nyinahini. Yam, however, is a crop cultivated in the arid and transitional zones of Ghana with Techiman, Atebubu and Kwame Danso being the major producing areas. The other producing areas were Ejura, Nkoranza and Tamale. Maize on the other hand thrives well in both the arid and forest zones of Ghana. Areas such as Ejura, Sekyedumasi, Techiman, Nkoranza, Goaso and their environs were cited by the traders as the sources of the foodstuffs they sell.

The traders either go directly to the places where these foodstuffs are cultivated or buy them from farmers who transport the commodities to the major markets to sell. About 56 per cent of the traders procured the foodstuffs from the farming communities at the farm-gate price whilst the remaining 44 per cent obtained their supplies from other major markets (such as Techiman and Ejura Markets in the case of yam) within the producing areas. Regarding the payment arrangements, 90 per cent pay fully for the foodstuffs, while the remaining 10 per cent make half payments and pay the difference after the sale of the foodstuffs. The study further identified that about 10 per cent of the traders support the farmers in the cultivation of the crops and are therefore given priority in the purchase of the foodstuffs from the entire farm. All these arrangements are based on mutual trust and oral agreements.
Through a focus group discussion with traders who cultivated the crops themselves, the study noted that they were compelled to transport and sell their produce directly in the markets due to the failure of middlemen/women to offer good prices for their produce. This finding is in line with the findings of Enete (2009) that middlemen/women exploit farmers by buying their produce at cheaper farm gate prices.

\section{Quantity of foodstuffs purchased}

The quantity of plantain and yam purchased by the traders ranged from 21 to 80 bunches and 1500 to 3500 tubers, respectively. For cassava, the traders bought quantities ranging from 5 to 14 sacks of an average weight of $50 \mathrm{~kg}$. Similarly, the maize sellers bought quantities ranging from 10 to 50 bags of an average weight of $100 \mathrm{~kg}$. The average number of bunches of plantain and tubers of yam purchased by the plantain and yam sellers was 78 bunches and 2,083 tubers respectively whilst for cassava and maize, the quantities purchased averaged 9 sacks of $50 \mathrm{~kg}$ and 30 bags of $100 \mathrm{~kg}$ respectively. However, the study identified that the male maize sellers bought about 40 bags $(100 \mathrm{~kg})$ of maize, that is, about 25 per cent more than their women counterparts who bought an average of 30 bags.

The quantity of foodstuffs purchased by the traders coupled with the distance (which ranged from $70-120 \mathrm{~km}$ ) covered to haul the foodstuffs to Kumasi influenced the means of transporting the foodstuffs. Out of the 90 plantain sellers interviewed, only 6.7 per cent and 13.3 per cent used "Trotro" (mini buses) and taxis respectively whilst the remaining 80 per cent use trucks (e.g. KIA trucks) as the mode of transport. Those who bought less than 40 bunches of plantain used taxis and "Trotro" as their means of transport. Thirty-three per cent of the cassava sellers used "Trotro" with the remaining 67 per cent using trucks to transport the cassava to the Kumasi Central and Race Course markets. On the other hand, all the yam and maize sellers used trucks due to their cost effectiveness. The use of trucks is seen to be cost effec- 
59

Baah-Ennumh and Adom-Asamoah

tive not only due to the bulky nature of the commodities but also due to the long distance covered.

From the focus group discussions with the trader associations as well as the drivers and the car owners, it came to light that there was some mutual understanding between them (drivers and traders). Each driver had a group of traders referred to as "customers" who were given priority in the transportation of their commodities. These customers were sometimes allowed to sell their goods before paying off their debts to the drivers. This special dispensation was given by the drivers in order to keep their customers and not lose them to other drivers.

Factors that determined the prices of foodstuffs in the markets

The first factor that determined the prices of foodstuffs was the farm gate price of the commodities. Most famers disposed off their produce after harvest due to lack of storage facilities. Due to this, the cost of foodstuffs fluctuated between the seasons (bumper and lean). In the lean season, prices of the foodstuffs could double especially for maize and yam due to high demand but limited supply as indicated in Table 1. In the case of cassava and plantain, the harvest from the farms reduced in the dry season which shot up the farm gate prices.
As indicated in Table 1, the cost of the foodstuffs increased substantially in the lean (minor) season due to high demand against limited supply. The increase in price was highest with maize which could experience an average of 137.5 per cent increase.

Cost of transport is seen as the other factor that determined the prices of foodstuffs. The total costs of transporting the foodstuffs was dependent on the quantity of foodstuffs transported by the traders, since transport operators charged per unit (bunches, sack, bag or tubers) of foodstuffs transported. With plantain, the amount charged by the transport operators ranged between 50GHp and $\mathrm{GH} \phi 1$ per bunch; between $50 \mathrm{GHp}$ and $\mathrm{GH} \phi 1$ and $\mathrm{GH} \phi 2.5-\mathrm{GH} \phi 10.00$ were the charges for cassava and maize, respectively. In the case of yam, transport operators charged between $\mathrm{GH} \phi 8$ and $\mathrm{GH} \phi 10$ for every 100 tubers that were transported. The cost of transporting an average of 66 bunches of plantain was $\mathrm{GH} \phi 42.9$ and constituted between 13.5 per cent and 21.5 per cent of the total sales. The situation was not different from the other foodstuffs as the transportation charges constituted approximately 20 per cent, 9 per cent and 10 per cent of the total sales from yam, cassava and maize, respectively. The transport operators were able to convey cassava, plantain and yam close to the points of sale. However, in the

Table 1: Differences in the prices of the foodstuffs in the major and minor seasons

\begin{tabular}{lcc}
\hline Quantity & Average amount $(\mathbf{G H} \boldsymbol{c})$ & Percentage change in prices \\
\hline Plantain & $2-4$ per bunch & - \\
Major season & $4-6$ per bunch & 66.7 \\
Minor season & & \\
Cassava & $2.0-2.5$ per sack $(50 \mathrm{~kg})$ & - \\
Major season & $3-4$ per sack $(50 \mathrm{~kg})$ & 55.6 \\
Minor season & $40-80$ per 100 tubers & - \\
Yam & $80-120$ per 100 tubers & 66.7 \\
Major season & & \\
Minor season & $30-50$ per maxi bag $(100 \mathrm{~kg})$ & - \\
Maize & $80-110$ per maxi bag $(100 \mathrm{~kg})$ & 137.5 \\
Major season &
\end{tabular}

Journal of Science and Technology @ KNUST August 2012 
case of maize, extra hands were required to facilitate the offloading and transfer to the sales point due to its bulky nature. According to the maize sellers, though transport operators have "mates" (i.e. assistants) who are to assist in the offloading of foodstuffs, sellers are expected to give them some "goodwill money" as a moral obligation for services rendered. The traders considered the transport charges (as identified above) exorbitant and therefore shifted all the cost to consumers by increasing the prices of the foodstuffs. In a focus group discussion, participants explained that the only way to maintain their profit margins was to increase the prices of their commodities to commensurate increases in transport charges.

\section{The traders' profit margin}

The study identified that all the market women engaged in the sale of the foodstuffs had limited operating capital ranging from $\mathrm{GH} \phi 100$ $\mathrm{GH} \notin 3,270$ as indicated in Table 2. The money was used for the purchase of the foodstuffs as well as paying for the complementary expenditure items (transportation charges, tolls and fees paid for safe storage of the commodities'watchman fee').

The total quantity of foodstuffs traded varied across the major and minor seasons as shown in Table 2. Plantain sellers sold an average of 66 and 53 bunches of plantain in the major and minor seasons, respectively. The corresponding average total cost of the same quantities of plantain ranged from $\mathrm{GH} \notin 262$ to 319.7 for the major and minor seasons, respectively. In the case of the cassava sellers, an average of 10 and 8.4 sacks were sold in the major and minor seasons, respectively. The quantities of cassava traded in the major and minor seasons were bought for $\mathrm{GH} \notin 29$ and $\mathrm{GH} \notin 33.6$ respectively. Similarly, yam sellers bought an average of 2,083 and $1,993.9$ tubers at costs of $\mathrm{GH} \phi$ 1,249.7 and $\mathrm{GH} \phi 1,595.2$ for the major and $\mathrm{mi}-$ nor seasons respectively. Lastly, maize sellers procured an average of 33 and 28 bags at the costs of $\mathrm{GH} \not 1,327$ and $\mathrm{GH} \not 1,656.7$ for the major and minor seasons respectively.
Beside the direct expenditure incurred in the purchase of the foodstuffs, the traders incurred extra costs for the transportation and storage of their commodities as revealed in Table 3. Additionally, each trader paid a flat toll of 10 pesewas per day to KMA. The total expenditure incurred by the traders, therefore, comprised of the real costs of the foodstuffs and the extra costs shown in Table 3. Plantain, cassava, yam and maize sellers bore additional costs of $\mathrm{GH} \phi$ 60.40, $\mathrm{GH} \phi 14.60, \mathrm{GH} \varnothing 192.30$ and $\mathrm{GH} \phi 224.60$ respectively per a return trip as indicated in Table 3.

In estimating the profits accrued to the traders of the four foodstuffs, the total expenditure which comprised the direct cost (cost of the foodstuffs) and indirect costs (costs of transporting the commodities to the markets, tolls paid to KMA and fees paid to security men for safe storage) were compared to the total revenue accrued to the business.

The total revenue from the sale of the quantities (66 and 53 bunches in the major and minor seasons) of plantain was between $\mathrm{GH} \phi 327.50$ and $\mathrm{GH} \phi 389.50$ for the major and minor seasons respectively, and profits ranged between $\mathrm{GH} \phi 5.10$ and $\mathrm{GH} \phi 9.20$ per week (refer to Table 4). Thus, the monthly profit was estimated to be $\mathrm{GH} \phi 20.40$ and $\mathrm{GH} \phi 36.80$ for the major and minor seasons respectively (these represent four return trips in a month).

Due to the perishable nature of cassava in relation to the other foodstuffs, it is purchased in smaller quantities and sold regularly within a maximum of two days by the traders. The total profits accrued to the activity ranged from $\mathrm{GH} \phi$ 4.40 and $\mathrm{GH} \not 10.50$ per a return trip (refer to Table 4). These yielded average monthly profits of $\mathrm{GH} \phi 52.80$ and $\mathrm{GH} \phi 126.00$ for the major and minor seasons respectively (for twelve return trips in a month).

The yams were purchased in larger quantities relative to plantain and cassava. The stock of an average of 2,083 tubers in the major season and 
61 Baah-Ennumh and Adom-Asamoah

Table 2: Traders profit margins

\begin{tabular}{|c|c|c|c|c|c|c|}
\hline \multirow{2}{*}{$\begin{array}{l}\text { Quantity of } \\
\text { foodstuffs (in } \\
\text { range) }\end{array}$} & \multicolumn{3}{|c|}{ Major Season } & \multicolumn{3}{|c|}{ Minor Season } \\
\hline & $\begin{array}{c}\text { No. of } \\
\text { traders }\end{array}$ & $\begin{array}{c}\text { Aver. } \\
\text { cost of } \\
\text { foodstuffs } \\
(\mathbf{G H})\end{array}$ & $\begin{array}{l}\text { Aver. } \\
\text { revenue } \\
\text { from sale } \\
(\mathbf{G H C})\end{array}$ & $\begin{array}{l}\text { No. of } \\
\text { traders }\end{array}$ & $\begin{array}{c}\text { Aver. } \\
\text { cost of } \\
\text { foodstuffs } \\
(\mathbf{G H C})\end{array}$ & $\begin{array}{c}\text { Aver. } \\
\text { revenue } \\
\text { from sale } \\
(\mathbf{G H e})\end{array}$ \\
\hline \multicolumn{7}{|l|}{$\begin{array}{l}\text { Plantain } \\
\text { (in bunches) }\end{array}$} \\
\hline $21-30$ & 12 & 102 & 127.5 & 22 & 153 & 191.25 \\
\hline $31-40$ & 6 & 142 & 177.5 & 9 & 213 & 266.25 \\
\hline $41-50$ & 6 & 182 & 227.5 & 9 & 273 & 336.25 \\
\hline $51-60$ & 6 & 222 & 277.5 & 15 & 333 & 406.25 \\
\hline $61-70$ & 6 & 262 & 327.5 & 12 & 393 & 476.25 \\
\hline $71-80$ & 24 & 302 & 377.5 & 8 & 453 & 546.25 \\
\hline Above 80 & 30 & 342 & 427.5 & 15 & 513 & 616.25 \\
\hline Average & & 262 & 327.5 & & 319.7 & 389.5 \\
\hline \multicolumn{7}{|c|}{ Cassava (in $50 \mathrm{~kg}$ weight of sacks) } \\
\hline 1- 5 sacks & 6 & 9 & 15 & 13 & 12 & 21 \\
\hline $6-10$ sacks & 48 & 24 & 40 & 57 & 32 & 56 \\
\hline $11-15$ & 36 & 39 & 65 & 20 & 52 & 91 \\
\hline Average & & 29 & 48 & & 33.6 & 58.7 \\
\hline \multicolumn{7}{|c|}{ Yam (in tubers) } \\
\hline $1500-1999$ & 54 & 1049.7 & 1399.6 & 64 & 1399.6 & 1749.5 \\
\hline $2000-2499$ & 18 & 1349.7 & 1799.6 & 12 & 1799.6 & 2249.5 \\
\hline 2500-2999 & 12 & 1649.7 & 2199.6 & 10 & 2199.6 & 2749.5 \\
\hline $3000-3499$ & 6 & 1949.7 & 2599.6 & 4 & 2599.6 & 3249.5 \\
\hline Average & & 1249.7 & 1666.3 & & 1595.2 & 1993.9 \\
\hline \multicolumn{7}{|c|}{ Maize (in $100 \mathrm{~kg}$ weight of bags) } \\
\hline $10-19$ & 6 & 580 & 870 & 18 & 870 & 1160 \\
\hline $20-29$ & 24 & 980 & 1470 & 38 & 1470 & 1960 \\
\hline $30-39$ & 48 & 1380 & 2070 & 22 & 2070 & 2760 \\
\hline $40-49$ & - & 1780 & 2670 & 12 & 2670 & 3560 \\
\hline $50+$ & 12 & 2180 & 3270 & - & 3270 & 4360 \\
\hline Average & & 1327 & 1990 & & 1656.7 & 2208.9 \\
\hline
\end{tabular}

Source: Field Survey, August 2009

minor seasons respectively. Thus, the yam sellers earned profits of $\mathrm{GH} \not 448.60$ and $\mathrm{GH} \phi$ 412.80 per month on the average from two return trips in the major and minor seasons respectively.

Maize provided the traders with average profits of $\mathrm{GH} ф 439.60$ and $\mathrm{GH} \notin 327.40$ for the major and minor seasons respectively. The stock of maize lasted relatively longer than the rest of the foodstuffs since the traders bought the commodity in its dried state. Most of the traders, however, reported that the profits earned from their businesses were inadequate to cater for their household needs. A comparison made between the traders' profit levels in the major and minor seasons revealed that the plantain and cassava sellers' profits increased in the 
Table 3: Additional costs incurred by the traders per return - trip

\begin{tabular}{|c|c|c|c|c|c|c|c|}
\hline \multirow[b]{2}{*}{$\begin{array}{l}\text { Type of } \\
\text { foodstuff }\end{array}$} & \multirow{2}{*}{$\begin{array}{l}\text { Quantity of } \\
\text { foodstuffs } \\
\text { transported }\end{array}$} & \multicolumn{5}{|c|}{ Items Under Expenditure } & \multirow[t]{2}{*}{ Total } \\
\hline & & $\begin{array}{c}\text { Transport } \\
\text { cost } \\
\text { (freight) per } \\
\text { a return } \\
\text { trip } \\
\text { GHc }\end{array}$ & $\begin{array}{c}\text { Tolls } \\
\text { (Tickets) } \\
\text { GHp }\end{array}$ & $\begin{array}{c}\text { Security } \\
\text { ('watchman' } \\
\text { fee) } \\
\text { GHe }\end{array}$ & $\begin{array}{c}\text { Head } \\
\text { porterage } \\
\text { GHd }\end{array}$ & $\begin{array}{l}\text { Wages } \\
\text { paid to } \\
\text { appren- } \\
\text { tices }\end{array}$ & \\
\hline Plantain & 66 bunches & 45.5 & 2.4 & 2.0 & 3.0 & 7.50 & 60.4 \\
\hline Cassava & 10 sacks & 5.2 & 2.4 & 2.0 & 2.5 & 2.50 & 14.6 \\
\hline Yam & 2,083 tubers & 169.4 & 2.4 & 2.0 & 3.5 & 15 & 192.3 \\
\hline Maize & $\begin{array}{c}33 \text { maxi } \\
\text { bags }\end{array}$ & 185.0 & 2.6 & 2.0 & 5.0 & 30 & 224.6 \\
\hline
\end{tabular}

Source: Field Survey, August 2009

Table 4: Traders' total expenditure and total revenue pattern - per a return trip

\begin{tabular}{lcccccc}
\hline $\begin{array}{l}\text { Type of } \\
\text { Foodstuff }\end{array}$ & $\begin{array}{c}\text { Major season } \\
\text { Total Expen- } \\
\text { diture (GHc) }\end{array}$ & $\begin{array}{c}\text { Total } \\
\text { Revenue }\end{array}$ & $\begin{array}{c}\text { Total } \\
\text { Profit }\end{array}$ & $\begin{array}{c}\text { Motal Expen- } \\
\text { diture (GHc) }\end{array}$ & $\begin{array}{c}\text { Total } \\
\text { Revenue }\end{array}$ & $\begin{array}{c}\text { Total } \\
\text { Profit }\end{array}$ \\
\hline Plantain & 322.40 & 327.50 & 5.1 & 380.300 & 389.50 & 9.2 \\
Cassava & 43.60 & 48 & 4.4 & 48.20 & 58.70 & 10.5 \\
Yam & 1442 & $1,666.30$ & 224.3 & 1787.50 & $1,993.90$ & 206.4 \\
Maize & 1551 & 1990 & 439 & 1881.30 & $2,208.90$ & 327.6 \\
\hline
\end{tabular}

Source: Field Survey, August 2009

minor seasons. Maize and Yam sellers however experienced decline in profit margins in the minor season which was as a result of higher expenditure incurred (see Tables 4 and 5).

The observed increases in the traders' profit levels were attributed to the scarcity of the commodities in the minor (dry) seasons whilst the demand for the commodities remained the same. The traders revealed that they were compelled to increase the selling prices of the commodities because their prices were higher in the minor seasons. The disproportionate increase in the prices of the commodities accounted for the increases in the profit levels.
The role of the market traders in the local economy

It was identified that market women play numerous roles in the development of the local economy. The roles are discussed below.

Revenue to Kumasi Metropolitan Assembly (KMA)

The taxes and rents paid by the traders were major sources of internally generated revenue to KMA. The taxes and rents were paid to KMA through the Market Management. The taxes were in the form of market tolls commonly referred to as "tickets" whilst the rents were paid to the Assembly for using the stores 
Table 5: The traders' profit levels in the major and minor seasons

\begin{tabular}{llll}
\hline Foodstuff & \multicolumn{2}{l}{ Seasonal Profits $(\mathbf{G H c})$} & Percentage change \\
& Major & Minor & \\
\hline Plantain & 5.10 & 9.20 & 80.4 \\
Cassava & 4.40 & 10.50 & 138.6 \\
Yam & 224.30 & 206.40 & -8.0 \\
Maize & 439 & 327.60 & -25.4 \\
\hline
\end{tabular}

Source: Field Survey, August 2009

and stalls provided for the traders. These traders paid amounts ranging from 5 - 10Gp a day to the management of the markets as tolls. This finding correlates well with the findings of Owusu and Lund (2004) and King (2006 cited in Brown 2006) that levies paid by women in the informal commercial sector contribute significantly to the internally generated funds of District Assemblies.

The foodstuff sellers in the Race Course market were however displeased with the performance of KMA towards meeting their infrastructural needs. Their displeasure with the performance of KMA was explained by the deplorable nature of their lanes especially when there is a downpour which affects their businesses. The study noted that KMA was handicapped in responding to their infrastructural needs because the traders were squatting on a private property (Daily Graphic, 2010). KMA, however, provided the market women particularly those in the Central Market with security and market structures (mainly sheds). It also ensured environmental quality and prevented encroachment on their lands by private developers. Several sensitisation programmes on simple records keeping, financial management, and good hygienic practice have been conducted for the traders by KMA and the Women's Department of the Ministry of Women and Children Affairs (MOWAC) with resource persons from a wide range of bodies including the National Board for Small Scale Industries (NBSSI) and the German International Cooperation (GIZ). However, the training programmes have had limited effect on the traders.

\section{Job Creation}

The traders generated both direct and indirect employment. The first group of people mentioned were drivers who earned their livelihoods by transporting the foodstuffs from the farm gates to the market centres. Additionally, security men, 'truck pushers' and head porters all gained employment due to the activities of the traders in the markets. This explains why the concentration of head porters was skewed towards the Kumasi Central Market and Race Course market whilst the direction of flow of goods was from the two markets to the bus terminals (i.e. Kejetia, Roman Hill and Doctor Mensah). The livelihoods of retailers in the satellite and other smaller markets across the metropolis were sustained by the credits offered to them by the traders. The foodstuff sellers' job creation role supports ILO's claim that the informal sector provides employment to about 61 per cent of the urban labour force in Sub Sahara Africa (ILO, 1998).

\section{Provision of income for households}

Though, to majority of the traders, the profits earned from their trade were not substantial to guarantee a better standard of living, they were able to augment their households' total income from the profits made. This role confirms Owusu (2007) claim that the informal economy is a source of supplementary income for households in many developing countries. Again, the finding relates well with earlier findings that the informal sector contributes significantly to households' total income in many regions of the developing world (Adarkwa and Post, 2001; Boapeah, 2001). 
Food security for the urban economy

The traders' role in ensuring food security and sufficiency in the urban areas is impeccable. This claim is underpinned by three main facts. Firstly, the transportation of the foodstuffs from the remote areas to the urban areas had reduced post harvest losses and motivated farmers to continue production due to the ready market made available by the traders. Secondly, the assistance (micro credits) given to farmers to invest in their farming activities had enabled the hitherto subsistence farmers to commercialise their activities. Lastly, the traders, especially the maize sellers, were able to preserve the foodstuffs in times of glut for future use during the lean season. All these efforts contributed towards the achievement of food sufficiency and security.

Development of entrepreneurial and managerial talents

Shortage of entrepreneurial and managerial talents has been observed as a handicap to economic development in the Less Developed Countries (Lane and Pollner, 2001). It thus implies that efforts should be made to provide a platform on which entrepreneurial skills could be learnt. In this respect, the traders had trained and continued to train people to acquire the necessary skills in trading. Sixty per cent of the traders interviewed had "apprentices" who supported them in their daily endeavours. These apprentices were either their wards or workers who were paid wages for the work they performed. An interview with the traders revealed that the apprentices were expected to start their own enterprises after acquiring the necessary skills. Furthermore, 30 per cent of the traders inherited the business from their parents and superiors after having acquired experiences from their servitudes.

Challenges of the market women in the urban informal economy

Despite the significant roles the traders play in the development of the local economy, their operations are engulfed by several challenges. The following were identified:
Improper record keeping practices

Majority (95.8 per cent) of the traders interviewed could not provide a documented record of the foodstuffs that they traded in. Due to this, profits or losses were not easily noticed by the traders. Additionally, measuring the performance of the business becomes a challenge for the traders. This is mainly blamed on the traders' low formal educational background. The few (4.2 per cent) that could provide a simple record of the business acquired the skills from the capacity building programmes organised by MOWAC.

Breakdown of vehicles in the process of transporting the foodstuffs

Another factor limiting the traders in the effective performance of their roles was the frequent vehicular breakdown. Foodstuffs such as cassava and plantain perish when kept in a vehicle for a long time due to vehicle breakdown. Transport operators confirmed the claim made by the traders about the frequent vehicular breakdowns. They attributed it to the rough terrains they ply to cart the commodities from the farm gates to the market centres.

\section{Limited infrastructure in the markets}

The traders complained of limited infrastructure such as sheds and toilet facilities in the markets particularly at the Race Course. Additionally, the lanes become muddy whenever there is a heavy rainfall and this affects the traders' businesses. The coping strategy for the traders has been to relocate to the main streets where there is continuous and uninterrupted demand. Space constraints also came up as an issue that needed to be addressed. Traders, particularly those at the Central market complained that the space allocated to them was small rendering their operations very inconvenient. This has resulted in the increasing desire of traders to get closer to the road.

\section{Time of closure from the markets}

The central market is opened for 12 hours from $6.00 \mathrm{am}$ to $6.00 \mathrm{pm}$ daily. According to the trade -based associations, the closing time was unfa- 
vourable against the background that there was patronage of the foodstuffs even after the markets were closed. The traders were thus compelled to move onto the streets after $6.00 \mathrm{pm}$ and obstruct the free movement of traffic.

\section{CONCLUSION}

The market women in the informal sector are playing crucial roles in supplying the food needs of the growing urban population and employing the labour force. These roles need to be acknowledged by policy makers and implementers in the national programmes of action. The paper has revealed that regular capacity building programmes, adequate basic infrastructure and formalisation of transport arrangements could enhance the operations of the women in the market. These will in turn facilitate the achievement of Ghana's poverty reduction agenda.

\section{RECOMMENDATIONS}

For enhanced performance of the market women towards the development of the urban informal economy, the paper recommends the following:

\section{Regular capacity building programmes}

Based on the fact that a greater percentage of the market women had weak and haphazard business arrangements, it is recommended that the KMA in collaboration with the NBSSI and the Women's Department of MOWAC organise regular marketing and managerial capacity training programmes for the traders to upgrade their business skills and capacity. Though, some ad hoc capacity building programmes were organised for the traders, their effectiveness had not been significant. For that reason, KMA and the other stakeholders (NBSSI, GIZ and the financial institutions) should endeavour to regularise the training programmes. Evaluation of the lessons taught should be an important component of the stakeholders' programmes of action. The evaluations would inform the nature of future interventions in the area of capacity building to enhance the roles of the traders towards the development of the urban economy.

Provision of basic infrastructural services The traders operating in the Kumasi Race Course market must be encouraged to relocate to the satellite markets to trade since the race course has been earmarked for the construction of a shopping mall and a hospital (Daily Graphic, 2010). This implies that adequate facilities such as stalls, stores, water and toilet ought to be in place for use by the traders at the satellite markets. Additionally, buyers must be encouraged to patronise the services of traders operating in the satellite markets. The shift of attention from the CBD to the satellite markets by the sellers and buyers would be possible if complementary services such as education, transportation and banking were provided. Thus buyers and sellers should not only have an easy access to the markets but also be able to perform multiple tasks similar to the Central Business District.

\section{Formalisation of transport arrangements}

To facilitate smooth and less costly transportation arrangements, the Trader Associations should collaborate with the various Transport Associations, particularly the Truck Drivers and the Transport Owners' Associations to formalise their charges. The Ghana Private Road Transport Union (GPRTU) and the Progressive Transport Union (PROTOA) should contact the trade-based associations to negotiate fares whenever there is the need to increase them.

\section{REFERENCES}

Adarkwa. K. K. and Post, J. (2001). The Fate of the Tree, Planning and Managing the Development of Kumasi, Ghana. Woeli publications services. Accra.

Akintoye, I. R. (2006) "Enhancing the performance of the Informal Sector for the Economic Development of Nigeria: A Case Study of Lagos State." International Journal of Social Sciences," 5(1):100-112.

Akintoye, I. R. (2008). “Reducing Unemploy- 
Market women in the informal urban economy...

ment through the Informal Sector: A Case Study of Nigeria." European Journal of Economics, Finance and Administrative Sciences, 11: 97-106.

Amis. P. (1995). "Making Sense of Urban Poverty." Environment and Urbanization, 7 (1):145-147.

Anarfi, J., Kwankye, S., Ofuso-Mensah A. and Tiemoko, R. (2003). Migration from and to Ghana: A Background Paper, Development Research Centre on Migration, Globalisation and Poverty, University of Sussex, Brighton.

Bacchetta, M., Ernst, E. and Bustamante, J. P. (2009). Globalization and Informal Jobs in Developing Countries, World Trade Organization Publications, Geneva, Switzerland

Boapeah, S. (2001). "The Informal Economy in Kumasi." In The Fate of the Tree, Planning and Managing the Development of Kumasi, Ghana. Edn Adarkwa, K. and Post, J. (2001), Woeli publications services, Accra.

Daily Graphic (2010). Race Course Area to become a Mega-business Centre, Accra, Communications Group. Paper Number 18342, pp 29. (29/09/2010)

Enete, A. A. (2009). "Middlemen and Smallholder Farmers in Cassava Marketing in Africa." Tropicultura, 27(1):40-44.

Garcia-Bolivar, O. E. (2006). Informal economy: is it a problem, a solution or both? The perspective of the informal business, The Berkeley Electronic Press, Berkeley, USA.

Ghana Statistical Service (2005). Population Data Analysis Report; Socio-Economic and Demographic Trends, Vol. 1 UNFPA funded Project (GHA/01/P07) Undertaken by Ghana Statistical Service.
International Labour Organisation (1998). "Women in the informal sector and their access to microfinance," Paper prepared by ILO for the Inter-Parliamentary Union (IPU) Annual Conference, Windhoek, Namibia, 2-11 April 1998.

International Labour Organisation (2000). Employment and social protection in the informal sector. First Item on the Agenda, Committee on Employment and Social Policy, 277th Session, GB.277/ESP/1/1.

King, R. S. (2006). "The Fulcrum of the Urban Economy: Governance and Street Livelihood in Kumasi, Ghana." In: Brown, A. (2006). Contested Space, Street trading, Public Space and Livelihoods in Developing Countries. Intermediate Technology Publication Ltd, Warwickshire, United Kingdom.

Lane, K. and Pollner, F. (2008). How to address China's growing talent shortage, in the Mckinsey Quarterly, 3:34-40.

Niels-Hugo, B., Sudharshan, C. and Dhushyanth, R. (2001). The Informal Sector Revisited: A Synthesis Across Space and Time, Social Protection Discussion Paper Series number 0119. Social Protection Unit, $\mathrm{Hu}-$ man Development Network, The World Bank.

Owusu, G. (2005). "Small Towns in Ghana: Justifications for their Promotion under Ghana's Decentralisation Programme." African Studies Quarterly, 8(2):48-69.

Owusu, F. (2007). "Conceptualizing Livelihood Strategies in African Cities: Planning and Development Implications of Multiple Livelihood Strategies." Journal of Planning Education and Research, 26(4):450-465.

Owusu, G. and Lund, R. (2004). "Markets and Women's Trade: Exploring their Role in District Development in Ghana." Norweg- 


\section{Baah-Ennumh and Adom-Asamoah}

ian Journal of Geography, 58(3):113 - 124.

Issues and Tools, Accra, Woeli Publishing Services.

Todaro, M. P. and Smith, S. C. (ed.) (2011). Economic Development, Tenth Edition, United Nations; Development Program (1999). Pearson Education Limited, England. Human Development Report 1999, New York, Oxford University Press.

Tsikata, D. (2001). Training in Ghana, Politics, 